\title{
CLAIMS FOR DISHONEST ASSISTANCE WITH BREACH OF TRUST, AND CHANGES MADE BY TWINSECTRA V YARDLEY
}

\author{
Andrew Woodcock, Cayman Islands Law School, Cayman Islands"
}

\section{Introduction}

Accessory liability - also commonly referred to as "knowing assistance" or "dishonest assistance" - is liability imposed by equity upon a third party for assisting in a breach of trust. The fundamentals for this cause of action in equity were established 130 years ago by the Court of Appeal in Barnes v Addy. ${ }^{1}$ It will be suggested that since that time, the principles underpinning the claim have evolved, such that - in material respects - the present version of the cause of action is quite markedly different from the original. Recently the House of Lords has been asked to revisit the question of what constitutes dishonesty, and it will be suggested that the House of Lords has significantly weakened the cause of action for future claimants. In purportedly seeking to endorse powerful statements made by Lord Nicholls in Royal Brunei Airlines Sdn Bhd $\mathrm{v}$ Tan, ${ }^{2}$ the majority of the House of Lords in Twinsectra $\mathrm{v}$ Yardley ${ }^{3}$ have fundamentally altered the approach of the courts to accessory liability. It will be argued that, in doing so, the House has substantially weakened the position of the beneficiary.

The modern foundation of dishonest assistance is to be found in the decision of the Court of Appeal in Barnes v Addy. ${ }^{4}$ This decision has been said to have founded the basis for liability of a third party (or a stranger) to a beneficiary under a trust. ${ }^{5}$ The facts of that case were, briefly, that Addy was the trustee of a fund. He purported to appoint Barnes as trustee of a half of the fund. However, this appointment was in breach of the trust instrument empowering the trustee to act. Nevertheless, Addy, as trustee, attended to the appointment of Barnes. The latter subsequently misappropriated the half of the fund of which he was trustee. As he subsequently became a bankrupt, there was no prospect of recovering that fund from Barnes. ${ }^{6}$

Proceedings were therefore commenced against both Barnes and the solicitors who had facilitated his appointment as a new trustee. The facilitation was effected by way of preparation and execution of the necessary documentation giving effect to his appointment. ${ }^{7}$ Importantly, Preston, the solicitor, was aware that it was in breach of trust for the

\footnotetext{
* The Author would like to thank Ms Susan Farran for her valuable comments on an earlier draft of this paper.

1 (1874) LR 9 Ch. App. 244.

2 [1995] 2 AC 378.

3 [2002] 2 AC 164.

4 (1874) LR 9 Ch App 244.

5 Peter Radan, Cameron Stewart, Andrew Lynch, Equity and Trusts, (Butterworths, Sydney, 2001) p.375.

6 (1874) LR 9 Ch. App. 244 at 246.

7 ibid., at 247.
} 
appointment to be made, and in fact advised the existing trustee to this effect. $^{8}$ This advice was acknowledged, but the trustee elected to proceed with the actions in any event. Preston therefore proceeded to act in accordance with his instructions, notwithstanding his misgivings.

Given that there was no principal against whom proceedings could be fruitfully brought, due to Barnes' insolvency at the time the misconduct was discovered, an action was brought against the solicitors, on the basis that the breach of trust could not have been carried out unless Preston had facilitated it. The solicitors were therefore said to be persons who had knowingly assisted in the breach of trust. ${ }^{9}$ The remedy sought against the solicitors was a declaration by the court that the solicitors were constructive trustees of the fund which had been dissipated by the misconduct of the errant trustee. This is, of course, a legal fiction, in that there was no longer any fund in existence.

This claim was rejected on the facts by the Court of Appeal. The leading judgment of the Court was delivered by Lord Selborne, who endorsed the principle, and set out the necessary criteria for finding accessory liability. In the 130 years following the decision, the observations of Lord Selborne have had substantial influence on the development of the law relating to knowing assistance. ${ }^{10}$ Perhaps more importantly, this judgment of His Lordship has been the subject of very wide and varied interpretation, with many differing views being taken of the meaning of His Lordship's words. ${ }^{11}$ It has been the subject of substantial interpretation and reinterpretation since the principles were originally laid down.

\section{Proprietary Remedy Versus Personal Remedy}

Before considering the specifics of knowing assistance in more detail, it should be borne in mind that there is some debate as to whether the remedy of constructive trust is in fact an appropriate remedy for claims of this type. The remedy of constructive trust is, at its heart, a proprietary remedy. The problem created by this remedy returns to the fact mentioned above, that the remedy is a legal fiction, and it has therefore been suggested that the remedy is not appropriate to cure the harm caused. ${ }^{12}$ That is, often there is no trust property to be found in the hands of the defendant, and the remedy is, in effect, the creation of a personal liability from the defendant to the beneficiary of the trust. ${ }^{13}$ Therefore, to endeavour to impose a proprietary remedy - when there is in fact no specific property which may be made the subject of the order - appears somewhat artificial.

The observations of Lord Browne-Wilkinson in Westdeutsche Landesbank Girozentrale v Islington London Borough Council ${ }^{14}$ have been used in support of this proposition. Lord Browne-Wilkinson makes the general observation in respect to equitable remedies that where there is receipt of a

8 ibid., at 248 .

9 ibid., at 250.

10 Denis Ong, Trusts Law in Australia (The Federation Press, Sydney, 2003) p.455.

11 On this point, note the diverging views within Twinsectra $\mathrm{v}$ Yardley.

12 G. E. Dal Pont and D. R C. Chalmers, Equity and Trusts in Australia, (Law Book Company, Sydney, 2004), p.980.

13 ibid.

14 [1996] AC 669. 
benefit with knowledge of the breach of a fiduciary duty, it gives rise to a personal liability. ${ }^{15}$ His Lordship further observes that the liability to account for a benefit, where there is the requisite knowledge, is substantially the same remedy as imposition of a constructive trust. He notes that the distinction "may only be a question of semantics". ${ }^{16}$

Notwithstanding this point by His Lordship, it must be viewed in the context of his earlier observation that the case of dishonest assistance in a breach of trust is a specific exception to the proposition that there must be identifiable trust property for there to be a constructive trust imposed on the defendant. ${ }^{17}$ The argument is therefore that courts of equity have taken the argument of artificiality into account, and accepted that it is a specific exception to the logical problem created by the imposition of a proprietary remedy over nonexistent property. This is supported by the nature of trusteeship, in that the obligation to account for the property over which the stranger is declared to be a trustee flows naturally from the duties imposed as trustee. Therefore, the argument is that the remedy of constructive trust is an appropriate one in cases of a stranger knowingly assisting in a breach of trust. ${ }^{18}$

The contrary argument is provided by Lord Millett in the more recent decision of Dubai Aluminium Co Ltd v Salaam. ${ }^{19}$ That case involved an allegation of dishonest assistance with a breach of fiduciary duty. It was asserted that two of the defendants, who were solicitors for the fraudsters, ought to be made constructive trustees in respect to the loss suffered by the plaintiff, on the basis that they dishonestly assisted in the breach of fiduciary duty. ${ }^{20}$

Lord Millett rejected this argument, and took the view that the term "constructive trustee" in such circumstances is - in his words "unfortunate". ${ }^{21}$ He observed that the person who, by participation in the fraud of another, interferes with the equitable interest of another ought to be made to account in equity for the loss suffered by reason of that interference. $^{22}$ However, that does not mean that the guilty party ought to be identified as a constructive trustee, for the primary reason that he is not the recipient of trust property. Therefore, the better way to express the liability ought to be as an obligation to account in equity for the loss suffered, but not necessarily as a constructive trustee, so-called. ${ }^{23}$

His Lordship quotes with approval the comment by Jules Sher QC in Coulthard v Disco Mix Club Ltd, ${ }^{24}$ where the point was made that this type of remedy is merely a mechanism created by the court for the purpose of granting relief. In support of this proposition, His Lordship prefers the idea

15 ibid., at 707.

16 ibid., at 707 .

17 ibid., at 705.

18 Dal Pont, op. cit., p. 1057

19 [2003] 1 All ER 97.

20 ibid., at 128.

21 ibid., at 131.

22 ibid., at 131.

23 ibid., at 131.

24 [1999] 1 All ER 457 at 479. 
of identifying the obligation to account in equity, even though in fact it has the same effect as the imposition of constructive trusteeship. ${ }^{25}$

Ultimately, however, it is submitted that the very point which is being made by Lord Millett, in light of the observations of Lord Browne-Wilkinson in Westdeutsche is somewhat self-defeating. The right of a beneficiary in respect to a declaration of constructive trust is to an account of the trust property, just as it is in respect to a non-proprietary remedy in the form of a personal order against the stranger to the trust. Therefore, it is largely a matter of nomenclature as to the identity of the particular remedy. This idea is further supported by the idea that the constructive trust is merely a "formula for equitable relief", ${ }^{26}$ making it clear that the declaration of constructive trust is a vehicle by which a court of equity will provide a remedy to an abused beneficiary.

The position is therefore not entirely clear as to whether the remedy imposed is a proprietary or personal one. It can be said with confidence that there is general, although not unanimous, agreement as to the form of the remedy that of a constructive trust. A constructive trust, by its nature, is a proprietary remedy. However, given that there is rarely any property in the hands of the liable defendant, in practical terms, the remedy is usually in the nature of a personal obligation to make good the loss suffered by the trust.

\section{Basis of Liability for Dishonest Assistance}

In respect to the claim against a third party for accessory liability, perhaps the most important, and most oft-quoted observation of Lord Selborne is his proposition that:

Those who create a trust clothe the trustee with a legal power and control over the trust property, imposing on him a corresponding responsibility. That responsibility may no doubt be extended in equity to others who are not properly trustees, if they are found either making themselves trustees de son tort, or actually participating in any fraudulent conduct of the trustee to the injury of the cestui que trust. But, on the other hand, strangers are not to be made constructive trustees merely because they act as the agents of trustees in transactions within their legal powers. ${ }^{27}$

Clearly, this statement allows a stranger to be innocent of the wrongdoing of the trustee where the stranger is fulfilling a lawful activity at the direction of the trustee. However, where the stranger undertakes an activity which facilitates the misconduct of the trustee, and does so with the knowledge that this is not in accordance with the terms of the trust deed, then such conduct must fall foul of the reasoning propounded by Lord Selborne. ${ }^{28}$ This will amount to knowing assistance in a breach of trust.

Therefore, the most important exception to the above proposition by Lord Selborne is where the assistance is provided in one of two circumstances. The first is where the stranger actually receives any part of the trust property,

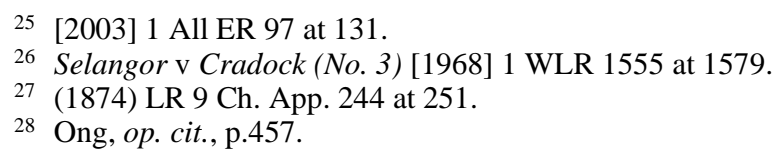


and the second is where the assistance is provided to the trustee "with knowledge of a dishonest and fraudulent design on the part of the trustee". ${ }^{29}$ It is this second limb from Barnes v Addy which is the subject of the present discussion, and the wording of which is the subject of such extensive debate.

Ultimately, in the Barnes Case, His Lordship accepted the evidence of the defendant solicitor that there was no reason to suspect any misconduct on the part of the trustee. Further, the fact that the solicitor provided advice to the effect that the transaction was not within the terms of the trust deed was, according to His Lordship, sufficient to satisfy him that there had been no dishonesty on the part of the solicitor. ${ }^{30}$ Consequently, His Lordship found that there was no basis for equitable intervention against the lawyer in the present case.

In a very real sense, this case is of great assistance in setting down the principles necessary to establish dishonest assistance. At the very least, it has set down the building blocks upon which the later courts have extensively built. However, equally, the case itself provides a somewhat unsatisfying conclusion on the facts. That is, it would appear on its face that the court failed to apply its own principles to the facts of the case before it.

Although the principal judgment in this case was delivered by Lord Selborne, there is an important addendum which has been added by Sir W. M. James LJ, which may be of assistance in the interpretation of Lord Selborne by later courts. James LJ made the following comment:

"I have long thought, and more than once expressed my opinion from this seat, that this Court has in some cases gone to the very verge of justice in making good to cestuis que trust the consequences of the breaches of trust of their trustees at the expense of persons perfectly honest, but who have been, in some more or less degree, injudicious. I do not think it is for the good of cestuis que trust, or the good of the world, that these cases should be extended." 31

The debate over the extent to which liability ought to be imposed on strangers to the trust relationship has focused almost exclusively on an interpretation of the comments of Lord Selborne. These observations of James LJ are made in the course of a vehement agreement with Lord Selborne. ${ }^{32}$ Therefore, when considering the intention of the court in this case, it is submitted that substantial assistance can be gained from incorporating this statement into any analysis. This is particularly so in respect to the issue of whether it is a question of knowledge or dishonesty required to attract liability. This matter will be discussed in more detail below.

29 (1874) LR 9 Ch. App. 244 at 252.

30 ibid., at 254.

31 ibid., at 256 .

32 ibid., at 255 . 


\section{Twinsectra v Yardley - A New Direction}

The most recent authoritative statement on this issue was made by the House of Lords in the matter of Twinsectra Ltd $\mathrm{v}$ Yardley. ${ }^{33}$ In that case, Twinsectra Ltd loaned the sum of $£ 1$ million to Yardley, for the express purpose of acquiring certain property. Yardley had two sets of solicitors, Sims and Leach. Sims provided an undertaking to Twinsectra that his firm would not release the funds to Yardley except for the purpose of the purchase of property. Leach was aware of that undertaking. In breach of the undertaking, Sims released the money to Leach. Leach, knowing that it was in breach of the undertaking, subsequently released the funds to Yardley, without confirming that the use of the funds was solely for the acquisition of property, pursuant to the arrangement. ${ }^{34}$ In fact, Yardley applied the funds to an unauthorised purpose, the funds were dissipated, and Twinsectra suffered a loss as a consequence. Twinsectra therefore commenced proceedings against Yardley, as well as the two solicitors; the latter on the basis of dishonest assistance to a breach of trust. ${ }^{35}$

The first point the court needed to establish was whether there was in fact a trust in existence, given that there was no express creation of a trust. Their Lordships in this case proceeded on the unanimous basis that the circumstances of the loan created a "Quistclose trust". ${ }^{36}$ Such a trust is often used as a de facto security arrangement, such that where funds are advanced for a specific purpose and that purpose has not been fulfilled at the point at which a company enters into liquidation, the funds will be said to have been held on trust by the company for the lender. ${ }^{37}$

In the present case, it was successfully argued that the undertaking provided by the first set of solicitors was sufficient to create a trust over the funds which were received by Yardley. ${ }^{38}$ In agreeing with the majority on this point (although dissenting on the major issue of the case), Lord Millett observed:

"Mr Sims undertook that the money would be used solely for the acquisition of property and for no other purpose; and was to be retained by his firm until so applied. ... "“

It is unconscionable for a man to obtain money on terms as to its application and then disregard the terms on which he received it. Such conduct goes beyond a mere breach of contract. ${ }^{39}$

His Lordship went on to observe that the duty which was created by the present circumstances was a fiduciary one, which was able to affect the

\footnotetext{
[2002] AC 164.

ibid., at 168 .

ibid., at 169 .

36 So called from the decision of the House of Lords in Barclays Bank Ltd $\mathrm{v}$ Quistclose Investments Ltd [1970] AC 567.

37 Joyce Lee Suet Lin, "Company Charges Under Singapore Law: Legal and Practical Implications", International Company and Commercial Law Review, 2003, p.2.

38 This was a unanimous determination.

39 [2002] 2 AC 164 at 186.
} 
interests of third parties. ${ }^{40}$ His Lordship observed that the key to the creation of an express trust is the intention of the settlor. Here, the wording of the undertaking, and the existence of the specific purpose for the fund amounted to an intention to create a trust. Therefore, even though the intention was not expressed as being to create a trust, it was nevertheless accepted that there was such an intention present on the part of the settlor. ${ }^{41}$

\section{Four Elements of Dishonest Assistance}

It was necessary for the court to establish that there was in fact a trust in place, as this is the first of the four elements to establish accessorial liability. ${ }^{42}$ That is, that there is a fiduciary duty of some type owed to the beneficiary. It has therefore been established that there is no longer a necessity for the claim to arise purely in circumstances of a breach of trust. This point was made by the House of Lords in Dubai Aluminium v Salaam. ${ }^{43}$ Lord Millett in that case accepted that a remedial constructive trust may be imposed where there is a breach of a fiduciary duty, as distinct from a breach of trust. ${ }^{44}$ Further, in the less recent Australian case of Consul Development Pty Ltd $\mathrm{v}$ DPC Estates Pty Ltd, ${ }^{45}$ the High Court of Australia proceeded on the basis that a breach of fiduciary duty and a breach of trust were essentially analogous. ${ }^{46}$ It can therefore be accepted that the principles espoused in Barnes v Addy, are today applicable both to allegations of breach of trust, and allegations of a breach of a less specific fiduciary duty.

The second element from Barnes v Addy is the requirement that there be a dishonest or fraudulent design of the trustee or fiduciary. ${ }^{47}$ This requirement has created slightly more difficulty in interpretation, and also reflects a point of departure between Australia and the United Kingdom, as there appear to be differing views between the courts of these countries as to the current interpretation of this proposition. ${ }^{48}$ The Australian courts would appear no longer to require that the breach of duty be fraudulent, whereas there is some confusion in the authorities which have come out of the United Kingdom as to whether the design is required to be fraudulent or otherwise in order for liability to attach. ${ }^{49}$

The Australian position is perhaps best stated by the High Court in Consul Development Pty Ltd v D P C Estates Pty Ltd. ${ }^{50}$ In that case, the plaintiff company operated a business whereby it purchased and renovated properties for the purpose of resale. A director of the plaintiff company identified a number of properties, and advised a director of the defendant company that they were worthwhile investments. He did so without the consent of the

40 ibid., at $186-187$.

41 ibid., at 187.

42 R. P. Meagher and W. M. C. Gummow, Jacob's Law of Trusts in Australia, Sydney: Butterworths, 1997, 338.

43 [2003] 1 All ER 97.

44 ibid. at 131.

45 (1975) 132 CLR 373.

46 In this respect, see especially Gibbs J at 398.

47 Barnes v Addy (1874) LR 9 Ch. App. 244 at 251-252.

48 Dal Pont, et al., op. cit., p.485.

49 ibid.

50 (1975) 132 CLR 373. 
plaintiff, and notwithstanding that he was acting on behalf of the plaintiff company at the relevant time that the properties were acquired. ${ }^{51}$ Importantly, however, at the time that the properties were acquired by the defendant, the plaintiff was not in a financial position to acquire those properties.

The High Court found in favour of the defendant on a majority of three to one; Justice McTiernan being the sole dissentient. Nevertheless, a preliminary issue to be determined was whether the plaintiff was entitled to a remedy where it was found that there was no dishonest or fraudulent design on the part of the fiduciary. In this case, it was a bare breach of fiduciary duty, which was actionable per se as between the beneficiary and the fiduciary. However, the question was whether that bare breach of fiduciary duty was sufficient to give rise to the entitlement of the beneficiary to bring proceedings against a third party who has interfered with the relationship between the fiduciary and beneficiary.

This point was not expressly and individually dealt with by any of the members of the court. Nevertheless, each member of the court proceeded on the basis that the breach of fiduciary duty in such case was sufficient to support the claim against the third party, in the event that the necessary criteria in respect to third party liability were made out. ${ }^{52}$ However, in the present case, the criteria in respect to the third party were not satisfied, and therefore there was no liability of the third party. The court was willing to accept that such liability was available in the absence of any actual fraud or dishonesty on the part of the fiduciary. ${ }^{53}$

The position is not nearly so clear in the United Kingdom. The Court of Appeal was asked to deal directly with the issue in Belmont Finance Corporation Ltd $\mathrm{v}$ Williams Furniture $L t d .{ }^{54}$ This was an appeal from a decision of the trial judge on a no case to answer submission. ${ }^{55}$ One of the issues for determination by the Court of Appeal was whether the plaintiff was required to plead that the beach of duty by the fiduciary was dishonest.

In this case, the Court held that, as it was a component of the original formulation of Lord Selborne that there should be dishonesty, there is no reason to depart from that formulation when determining whether there ought to be liability imposed on a third party. ${ }^{56}$ Buckley LJ observed that the phrase "fraudulent or dishonest" simply meant dishonesty. That is, he found that the words were synonymous. ${ }^{57}$

A similar point was made by Goff LJ in his judgment in the same case. His Lordship dealt briefly with the matter, but essentially reiterated the point which was made by Buckley LJ. However, the emphasis of Goff LJ seemed to lie in the risk of uncertainty, in the event that there is a departure from the words of Lord Selborne. He posed the question as to what level of

51 (1975) 132 CLR 373 at 374-5.

52 See, e.g. (1975) 132 CLR 373 at 398, per Gibbs J and at 413, per Stephen J.

53 Ong, op. cit., p.485.

54 [1979] Ch 250.

55 ibid. at 254.

56 ibid. at 267, per Buckley LJ.

57 ibid. at 267. 
impropriety on the part of the trustee is sufficient, if dishonesty is too strict a test. Goff LJ refers to venturing into an "uncharted sea", and agreed with Buckley LJ that this course would be dangerous. ${ }^{58}$ Therefore, it would appear the position in the United Kingdom is that there is actual dishonesty required on the part of the fiduciary in order for the third party to be able to be held accountable.

Nevertheless, the relatively recent decision of the Privy Council in Royal Brunei Airlines Sdn Bhd $\mathrm{v}$ Tan $^{59}$ has made the position in the United Kingdom less clear. In that case, Lord Nicholls delivered the advice of the Board. He specifically rejected the idea that there must be dishonesty on the part of the fiduciary in order for there to be any possibility of liability of the third party. ${ }^{60}$ In reaching this conclusion, His Lordship focused on the fact that the liability in question was a fault-based liability being imposed on the third party. The principal issue is the fault of the third party, and not the fault of the fiduciary or trustee. Therefore, it ought to be possible to impose liability on a third party, irrespective of whether there has been any dishonest conduct by the fiduciary, provided the necessary impropriety on the part of the third party is ascertained. ${ }^{61}$ Quite reasonably, His Lordship notes the corollary of the alternative argument, which is that if a fiduciary is honest, and the conduct of the third party is dishonest, the dishonest third party will escape liability. ${ }^{62}$ Clearly, this is an unsatisfactory result, which will be avoided by the formulation proposed in Lord Nicholls' judgment.

Unfortunately Lord Nicholls did not specifically address the decision of the Court of Appeal in Belmont Finance in this context. His Lordship's comments set out above effectively deal with the objections raised by Goff LJ in his judgment in that case. However, Lord Nicholls did not expressly apply his comments as to an innocent fiduciary to the judgments of Buckley and Goff LJJ. The difficulty which therefore creates the confusion is that Royal Brunei Airlines is a decision of the Privy Council on appeal from the Court of Appeal of Brunei Darussalum, and does not directly overrule a determination of the Court of Appeal, insofar as it applies to the law of the United Kingdom. ${ }^{63}$ Consequently, the observer is left to assume that any subsequent determination by the House of Lords will follow the Privy Council in Royal Brunei Airlines. ${ }^{64}$

This point was borne out by the recent decision of the Privy Council in Agnew $\mathrm{v}$ Commissioner of Inland Revenue, ${ }^{65}$ on appeal from the New Zealand Court of Appeal, regarding issues of fixed and floating charges. Although the Board expressly disapproved the decision of the Court of Appeal in In re New Bullas Trading Ltd, ${ }^{66}$ that decision stood until 2005, when the House of Lords expressly overruled it in In re Spectrum Plus Ltd

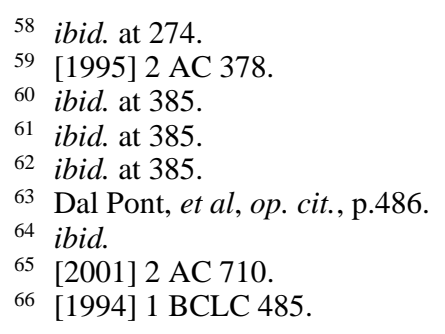


(in liquidation). ${ }^{67}$ Hence, until the House of Lords expressly overrules the Belmont Finance decision, it must be accepted that it remains valid - albeit somewhat questionable - law.

It may, however, be said that one of the weaknesses of the reformulation of the test by Lord Nicholls is that he did not consider the question in the context of the original formulation by Lord Selborne. ${ }^{68}$ Lord Selborne expressly stated the requirement for liability to be imposed on third parties as arising in circumstances where the third party has "assist[ed] with knowledge in a dishonest and fraudulent design on the part of the trustee". ${ }^{69}$ Given that Lord Nicholls was deciding on third party liability which was founded on the observations of Lord Selborne, it would have been convenient to provide some explanation as to the reason for departing from the specific formulation set out by the earlier court. Nevertheless, it is submitted that, for the very reasons stated by Lord Nicholls, the refinement offered in Royal Brunei Airlines is not inconsistent with the fundamental principle espoused in Barnes v Addy, which is to exonerate "persons dealing honestly" 70 with trustees who breach a trust, yet to render liable those who deal dishonestly, or with knowledge of dishonesty. Therefore, those who behave dishonestly ought to be found liable. Although this is implied on the face of the judgment of Lord Nicholls, it would have been a useful distinction to have made the point expressly, particularly in light of the comments of Goff LJ in Belmont Finance.

It is equally unfortunate that Twinsectra $\mathrm{v}$ Yardley was not a case which leant itself to resolution of the situation. There was no doubt in Twinsectra that the conduct of the trustee was fraudulent or dishonest, for the purposes of Lord Selborne's comments. Therefore, the House of Lords did not find it necessary to consider the question. It has therefore been left to another time for consideration.

This then leads to the third element of a dishonest assistance claim, which is arguably the least controversial of all of the elements of the claim. That is, the proposition that the third party must actually provide some assistance to the trustee or fiduciary in the carrying out of the breach of trust. ${ }^{71}$ Once again, a reference to the judgment of Lord Selborne in Barnes v Addy will offer some insight into what is expected in such a case.

In that case, the solicitor who was subject to attack prepared the trust deed which permitted the trustee to commit the dishonest act in respect to the subject-matter of the trust. ${ }^{72}$ However, Lord Selborne found that, in the absence of misconduct by the third party, merely acting as an agent for the trustee is not sufficient to hold the third party charged as a trustee. ${ }^{73}$ Therefore, standing alone, the conduct of the third party was simply said to have facilitated the breach of trust, but it was not sufficient to hold the third party liable. His Lordship made it clear that the additional conduct, in the

67 [2005] 2 AC 680.

68 Barnes v Addy (1874) LR 9 Ch App 244 at 251-252.

69 ibid., at 252.

70 ibid., at 252.

71 Meagher and Gummow, op. cit., p.338.

72 Barnes v Addy (1874) LR 9 Ch. App. 253.

73 ibid. 
form of knowledge of the breach of trust (although this issue of knowledge will be considered in more detail below) was necessary before there can be said to have been any basis for making the third party a constructive trustee. ${ }^{74}$

Once again, the question of what is necessary to amount to assistance was not addressed in Twinsectra, as it was not an issue as between the parties. There was no argument that the conduct of the defendant solicitors was sufficient to have assisted the breach of trust. However, what can be taken from the observations of Lord Selborne on this issue is that there are two limbs which must be satisfied. The first is that the conduct of the third party must be such as to facilitate the breach of trust. The second, which appears to be inextricably interwoven with the first, is that the facilitation must be with the knowledge that it amounts to a breach of trust (or fiduciary duty). Effectively, this makes it something of a fallacy to say that this is a separate element to the claim of knowing assistance.

This then leads logically to the final, and certainly the most controversial of the elements of knowing assistance. That is, the requirement - as formulated by Lord Selborne - that there be knowledge of the dishonest and fraudulent design of the trustee. ${ }^{75}$ The reason it is controversial is that, sadly, Lord Selborne provided no clear definition in his statement for the level of knowledge which is required for a third party to be captured. This is the area in which Twinsectra has made the greatest impact.

\section{Knowledge and Honesty}

It is in respect to the question of knowledge that Twinsectra ${ }^{76}$ finds its greatest importance, and in which the most deleterious effect of the decision is to be found. After the powerful statement of the law set out by Lord Nicholls in Royal Brunei Airlines $v$ Tan, ${ }^{77}$ the position in relation to such claims shifted from "knowing assistance" to "dishonest assistance". ${ }^{78}$ Lord Nicholls made it clear that the final - and most important - test was whether the third party had acted dishonestly in assisting the breach of trust. ${ }^{79}$ Nevertheless, the subsequent decision of the House of Lords in Twinsectra would appear to have made the prescription by Lord Nicholls less clear than it may appear on its face.

In addressing the question of what standard of conduct meets the test set out by Lord Selborne, Lord Nicholls in Royal Brunei starts with the proposition that the guiding principle is not to be the criminal standard. ${ }^{80} \mathrm{He}$ goes on to observe that the concepts of "acting dishonestly" and "a lack of probity" are terms which are synonymous. Ultimately, he says that it "means simply not

74 ibid., at 254.

75 ibid.

76 See Robert Hunter, "The Honest Truth About Dishonesty", Private Client Business, 2002, p. 390.

77 [1995] 2 AC 378.

78 G. E. Dal Pont, D. R. C. Chalmers, J. K. Maxton, Equity and Trusts: Commentary and Materials, (Law Book Co., Sydney, 2004) p.1051.

79 Hunter, op. cit., p.391.

80 [1995] 2 AC 378 at 389. 
acting as an honest person would in the circumstances." that this explanation is as clear as possible, he goes on to observe that the standard to be applied to determine whether a person has been acting as an honest person is an objective test.

Prior to the Royal Brunei Airlines case, the primary test for whether a third party was liable for misconduct relied on the words of Lord Selborne, to the effect that the assistance was given in the knowledge of the fraud or dishonesty of the trustee. ${ }^{82}$ In support of this position, Peter Gibson J, in the case of Baden v Societe Generale pour Favoriser le Developpment du Commerce et de L'Industrie en France $S A,{ }^{83}$ put forward the proposition that there are five standards of knowledge. They are best described as:

1. Actual knowledge;

2. Wilfully shutting one's eyes to the obvious;

3. Wilfully and recklessly failing to make such enquiries as an honest and reasonable person would make;

4. Knowledge of circumstances which would indicate the facts to an honest and reasonable person;

5. Knowledge of circumstances which would put an honest and reasonable person on enquiry. ${ }^{84}$

Until Royal Brunei Airlines v Tan, these five levels of knowledge were taken by the courts as the starting point for determining the level of knowledge required to satisfy Lord Selborne's criterion of assisting a fraudulent breach of trust with knowledge of the fraud or dishonesty. The principal question, however, was which of the five categories of knowledge would be sufficient in order to satisfy the criterion.

It is self-evident that actual knowledge will be sufficient to satisfy the requirement. The important question then is whether constructive or imputed knowledge will also be sufficient. ${ }^{85}$ Lord Selborne himself observed that it would be an unsatisfactory precedent to set to require that in every case where there was a "doubtful transaction", the solicitor or other agent responsible for assisting that transaction is thereby made a constructive trustee. ${ }^{86}$ This probably suggests that Lord Selborne was counselling against accessory liability being imposed on the basis merely of constructive notice..$^{87}$

The second category of knowledge - also referred to as 'Nelsonian' knowledge - has also been accepted as being sufficient to give rise to accessory liability. Buckley LJ confirmed this in Belmont Finance Ltd $\mathrm{v}$ Williams Furniture (No. 1), ${ }^{88}$ when he observed:

81 ibid., at 389.

${ }^{82}$ Radan, et al, op. cit., p. 376.

83 [1992] 4 All ER 161.

84 Set out in Radan, op. cit., p.376.

85 Ong, op. cit., p.460.

86 Barnes v Addy (1874) LR 9 Ch. App. 244 at 253-254.

87 Ong, op. cit., p.461.

88 [1979] Ch 250. 
"If he wilfully shuts his eyes to dishonesty, or wilfully or recklessly fails to make such enquiries as an honest or reasonable man would make he may be found to have involved himself in the fraudulent character of the design, or at any rate to be disentitled to rely on actual knowledge of the design as a defence." 89

This confirms that, where a third party simply ignores circumstances which ought to inform him of the existence of fraud or dishonesty by the trustee or fiduciary, the third party will be liable if he provides the relevant assistance in any event, notwithstanding that notice..$^{90}$ This point was recently reiterated by Lord Clyde in Manifest Shipping Co Ltd $\mathrm{v}$ Uni-Polaris Insurance Co $L t d,{ }^{91}$ when he observed that for "blind eye knowledge" to impugn the conduct of a party, it must be established that there was a reasonable basis for the relevant party to believe that it was best not to investigate, for fear of learning an unwelcome truth. ${ }^{92}$

The decision of the High Court of Australia in Consul Development Pty Ltd $\mathrm{v}$ D P C Estates Pty Ltd ${ }^{93}$ arguably represents something of a watershed in the move by Australian courts from knowledge-based liability to the focus on dishonesty, notwithstanding that the High Court in that case continued to focus on the knowledge of the third party. However, the High Court in this case looked at the level of knowledge of the third party, and determined whether that level of knowledge would have led an honest and reasonable man to the conclusion that there was impropriety by the trustee or fiduciary. ${ }^{94}$ In this vein, Stephen J referred to the "reasonable, honest man", ${ }^{95}$ when assessing whether the third party ought to be found liable as an accessory to the breach of duty by the trustee or fiduciary.

It is for this reason that this case can be said to be a watershed in the development of the law in Australia: the High Court accepted that the test as applied by Lord Selborne is the knowledge of the third party. However, it was equally accepted that the standard to be applied in determining whether the third party had the requisite knowledge was the test of the honest and reasonable man. ${ }^{96}$ Although this decision pre-dated the decision of Peter Gibson $\mathrm{J}$ in Baden, ${ }^{97}$ the High Court in any event did not find it necessary to address the question of standards of knowledge, other than the direct dichotomy of actual knowledge, and that of the honest and reasonable man.

Lord Nicholls, in Royal Brunei Airlines, goes further than the Australian courts, and suggests that the five levels of knowledge set out by Justice Peter Gibson are "best forgotten". 98 In reaching this conclusion, His Lordship is most concerned with the standard of the honest person. He adopts the view

89 ibid., at 267.

90 Meagher and Gummow, op. cit., p.333.

91 [2003] 1 AC 469.

92 ibid., at 472.

93 (1975) 132 CLR 373.

94 ibid., at 398 per Gibbs J.

95 ibid., at 413.

96 Ong, op. cit., p.483.

97 [1992] 4 All ER 161.

98 [1995] 2 AC 378 at 392. 
that the test for whether a third party ought to be liable rests on the issue of honesty, rather than knowledge, although it is clear that the knowledge of the third party is arguably a decisive factor in determining whether the third party has behaved honestly. ${ }^{99}$

As an illustration of what constitutes dishonesty for present purposes, he arguably goes beyond what is ordinarily understood by the term. ${ }^{100} \mathrm{He}$ makes the general comment that merely making an investment with some risk is not dishonest. However, where there is such a degree of unnecessary risk that the investment or other act amounts to recklessness, then the conduct may be said to amount to dishonesty on the part of the third party. ${ }^{101}$ Clearly, then the concept of dishonesty as espoused by Lord Nicholls is broader than that which would be understood in ordinary parlance. It naturally incorporates the meaning that would be taken by an "honest and reasonable man", but goes further to cover reckless conduct and the taking of unnecessary risks. ${ }^{102}$

As noted above, the observations of James LJ in Barnes v Addy ${ }^{103}$ seem to support the position adopted by Lord Nicholls. James LJ's comments have, unfortunately, been largely forgotten, having been overshadowed by the judgment of Lord Selborne. However, the fact that James LJ refers to the honesty of the third party is indicative that the reformulation of the test by Lord Nicholls is consistent with the original reasoning in Barnes v Addy.

This new approach to the formulation of accessory liability appears, on its face, to be relatively straightforward, and allows for ease of application in new circumstances. However, this has been shown not to be the case, with the decision of the House of Lords in Twinsectra v Yardley. ${ }^{104}$

Notwithstanding the observations of Lord Nicholls - and in purported reliance on the principles set out in his judgment - the majority of the House seemed to take yet another new position as to the appropriate test to apply in such circumstances. It is submitted that the powerful dissent of Lord Millett is the preferred position. However, this is merely a dissent, and therefore, the law is as stated by the majority.

The leading speech of the majority was delivered by Lord Hutton. In addressing the question of the standard to be applied to determine whether a third party is dishonest, His Lordship seized upon the fact that Lord Nicholls had said that the test is not wholly objective, as there must be some consideration of the knowledge of the defendant, in order to address the question of honesty. ${ }^{105}$ However, in interpreting this proposition, Lord

99 ibid., at 392.

100 Alastair Hudson, "Constructive Trusts and the Liability of Banks and Fund Managers", Journal of International Financial Markets, 2000, p.213.

101 [1995] 2 AC 378 at 389. This was nothing new, however, as the House of Lords had made the point over 100 years earlier in Derry v Peek [1886-1890] All ER1 that proof of recklessness was sufficient to make out fraud on the part of a defendant, for the purposes of pursuing an action in deceit.

102 Hudson, op. cit., p. 213

103 (1874) LR 9 Ch App 244 at 256.

104 [2002] 2 AC 164.

105 [1995] 2 AC 378 at 389. 
Hutton sought to narrow the effect of this observation, and effectively converted the primarily objective test proposed by Lord Nicholls into a subjective one. Lord Hutton stated:

"I think that in referring to an objective standard Lord Nicholls was contrasting it with the purely subjective standard whereby a man sets his own standard of honesty and does not regard as dishonest what upright and responsible people would regard as dishonest." 106

In making this observation, Lord Hutton potentially left it open to allow a third party to escape an allegation of dishonesty if that third party can establish that, on the basis of what the person knew at the time of the relevant incident, an honest and reasonable person would not have regarded the conduct as dishonest. ${ }^{107}$

This proposition is endorsed by Lord Slynn. He accepted that the defendant in the present case "deliberately shut his eyes" to the circumstances of which he ought to have been aware at the time of making the disbursement. ${ }^{108}$ However, on the basis of the reasoning of Lord Hutton, Lord Slynn was able to conclude that the defendant "may have been naïve or misguided", 109 but he was also able to conclude that the conduct did not amount to dishonesty. This is because the application of the test adopted by the majority was such that the circumstances of which the defendant was aware at the relevant time were found not to be such that an honest and reasonable man would have found that the conduct of the defendant was dishonest.

Further support for this idea is to be obtained from Lord Hoffmann. His Lordship accepted that the defendant was aware of all of the material facts in the case. However, he goes on to observe that ". . . he took a blinkered approach to his professional duties as a solicitor, or buried his head in the sand (to invoke two different animal images). But neither of those would be dishonest." 110 Lord Hutton agreed that the defendant "deliberately shutting his eyes to the problems and to the implications of the undertaking" 111 nevertheless did not amount to dishonesty.

The clear problem with the approach taken by the majority is that notwithstanding the overt acceptance that the test is an objective one - a subjective test of honesty is applied. The manner in which this has been applied clearly does not accord with the statements of Lord Nicholls, who was entirely plain in his statement that the test of honesty is an objective one. In making this point, he expressly referred to the criminal standard of honesty, and observed that this is not the standard which ought to be applied. ${ }^{112}$ The criminal test is that the defendant must be cognisant of his own wrongdoing for there to be dishonesty found in respect to his conduct. ${ }^{113}$

106 [2002] 2 AC 164 at 173.

107 ibid., at 174 .

108 ibid., at 167.

109 ibid., at 167 .

110 ibid., at 170

111 ibid., at 179 .

112 [1995] 2 AC 378 at 385.

113 See $R$ v Ghosh [1982] 2 All ER 689. 
It is apparent from a reading of the judgment of Lord Hutton, and the other members of the majority, that they have sought to apply something approaching the criminal test of dishonesty.

Lord Nicholls was applying what may be regarded as a mixed test of dishonesty. That is, he suggested that the standard ought to be objective, in that it is necessary to look at what a reasonable and honest person would do in the circumstances of the defendant. However, it is - to a limited extent only - also subjective, in the sense that the fictitious honest and reasonable person is expected to act on the basis of the knowledge of the defendant at the time the events occur. ${ }^{114}$ To that extent, the test is a "mixed" one, but it is clear on the face of the judgment of Lord Nicholls that the emphasis is definitely leaning towards the objective aspect of the test. This proposition may be further endorsed by extrinsic developments in the law relating to trustees, such as the clarification of the duty of care in the Trustee Act $2000 . .^{115}$

In contrast, despite the assertion by both Lords Slynn and Hutton that they accept the formulation of honesty as prescribed by Lord Nicholls, it is apparent that a subjective test is applied. From the nature of the comments and most importantly, the conclusions - of the majority, it is clear that the fact that the defendant was found not to have any dishonest intent was held to be sufficient to vindicate him. That is, the criminal test of dishonesty was applied, and it was found that the defendant did not intend to act dishonestly. This is as opposed to considering whether an honest and reasonable person in the position of the defendant would have acted in the same way. Therefore, the defendant was found not to be liable. With respect, it is submitted that this is an inappropriate application of the test propounded by Lord Nicholls.

Lord Millett provides a much clearer - and, it is submitted, more accurate statement and application of the principles from Royal Brunei Airlines v Tan in his dissenting speech. Interestingly, Lord Millett relies on the same passage from Royal Brunei Airlines v Tan as Lord Hutton, in which Lord Nicholls states that the test is not the criminal law test for honesty, but rather want of probity. ${ }^{116}$ However, the conclusion reached by Lord Millett is that the intention of Lord Nicholls was not to focus on the dishonest state of mind of the defendant, but rather to focus on the dishonesty of the conduct. ${ }^{117}$ Most importantly, Lord Millett rejects the idea that there is any suggestion by Lord Nicholls that the defendant must have any knowledge that he was doing wrong. ${ }^{118}$ This is an essential difference between the decision of the majority and that of Lord Millett.

Lord Millett does not expressly suggest that the test applied by Lord Nicholls is a "mixed" one. However, he does implicitly acknowledge this to be the case when he notes that the standard to be achieved by the third party is that of "an honest person placed in similar circumstances". ${ }^{119}$ Naturally, there is some limited, but essential, element of subjectivity in this formulation, in

114 Panesar, op. cit., p.13.

115 Contained in section 1.

$116 \quad[1995] 2$ AC 378 at 389.

117 [2002] 2 AC 164 at 197.

118 ibid., at 197.

119 ibid., at 198. 
that the particular circumstances of the defendant must necessarily govern the response of that person at any given time. Therefore, although there may be no intention to act dishonestly within any given circumstances, the conduct of a defendant may be found to be dishonest if the response to those conditions does not meet the standard of an honest and reasonable person with the same characteristics, and in the same position.

The conclusion of the various judges in this case illustrates the importance of the distinction between the two methods of interpretation. The majority accepted that the defendant was aware of all of the relevant facts, and that he closed his eyes to circumstances which may have indicated impropriety. However, it does seem to be common ground that the defendant did not have actual knowledge of the fraud or dishonesty. That being the case, the majority were prepared to absolve the defendant on the basis that he meant no harm or dishonesty. Conversely, Lord Millet, in applying (correctly, it is submitted) the test of honesty from Lord Nicholls, found that this conduct would amount to dishonesty, because an honest and reasonable person would have found the actions of the defendant, in all of the circumstances, to have been dishonest. The interpretation adopted by the majority renders the position of the beneficiary much weaker, and makes it potentially much more difficult to impose liability on a third party.

\section{Recent Attempts at Clarification}

The principles in Twinsectra were recently considered by the Privy Council in an appeal from the Isle of Man, in the case of Barlow Clowes International v Eurotrust International Ltd. ${ }^{120}$ Lord Hoffmann delivered the advice of the Board in this case. In doing so, he referred to Lord Hutton's comments from Twinsectra that ". . . for liability as an accessory to arise, the defendant must himself appreciate that what he was doing was dishonest by the standards of honest and reasonable men." ${ }^{21}$ This purported imposition of a subjective test has been the subject of some criticism since the Twinsectra decision, which Lord Hoffmann notes in his preliminary comments. ${ }^{122}$ It is this alleged imposition of a subjective test which his Lordship sought to clarify in the Barlow Clowes case.

Although the Privy Council sought to clarify the position, in fact it is respectfully suggested that they have sought to provide a retrospective revision of the words of the court in the earlier case, and in doing so have provided a new - and somewhat contradictory - interpretation. Lord Hoffmann, in referring to the speech of Lord Hutton, states:

"The reference to "what he knows would offend normally accepted standards of honest conduct" meant only that his knowledge of the transaction had to be such as to render his participation contrary to normally acceptable standards of honest conduct. It did not require that he should have had

120 [2005] UKPC 37

121 [2002] 2 AC 164 at 174.

122 [2005] UKPC 37, para.15. 
reflections about what those normally acceptable standards were." 123

Similarly, his Lordship considered his own speech in Twinsectra, and once again noted that the intention was that the defendant must have knowledge that the conduct breaches the ordinary and acceptable standards of behaviour, but it is not necessary for the plaintiff to show that he reflected on what those standards are. ${ }^{124}$ Finally, his Lordship concludes that "the principles of liability for dishonest assistance which had been laid down in Twinsectra . . . were no different from the principles stated in Royal Brunei Airlines v Tan . . .". ${ }^{125}$ Therefore, the conclusion must necessarily be that the House of Lords in Twinsectra was not imposing a subjective test, but an objective one.

With respect, this conclusion is erroneous on two main grounds. The first is that, on its face, the words of the members of the House in Twinsectra reflect a significant move away from the position of Lord Nicholls in Royal Brunei, for the reasons set out in some detail above. The observations of the majority in Twinsectra clearly reflect what might be argued as a more 'defendant friendly' approach to the level of knowledge required for liability to attach for dishonest assistance.

Secondly, as is suggested above, this decision clearly amounts to a retrospective attempt to give an alternate - and somewhat confusing meaning to words which are clear on their face. Lord Hoffmann suggests that the intention of the majority in Twinsectra was to conclude that the defendant was liable where he knows that his conduct is dishonest, but that it is not part of the test to establish that the defendant gave any thought to what constitutes dishonesty. The critical element of subjectivity - being the defendant's appreciation of what constitutes dishonesty - is removed from the test.

This is, however, a logical impossibility. It is not possible for a rational creature to have knowledge of a legal or moral position - such as the honesty or dishonesty of an act - without reflecting upon the essentials of that legal or moral position. If knowledge of dishonesty is the determinant of liability, then the test remains a subjective one, and the Twinsectra and Royal Brunei tests continue to diverge. It is therefore suggested that the Privy Council's attempt to reconcile these two cases has failed.

\section{Consequences and Conclusion}

It is submitted that there is a potentially significant negative consequence arising from the decision of the House of Lords in the Twinsectra case. The imposition of what is effectively a subjective test of dishonesty imposes a standard of dishonesty which falls only a little short of requiring an intention to commit a dishonest act. ${ }^{126}$ Consequently, it could easily be suggested that there is little value remaining in the action based upon the second limb of

123 ibid., para.15.

124 ibid.. para.16.

125 ibid., para. 18 .

126 Georgina Andrews, "The Redundancy of Dishonest Asisstance”, Conv., Sept/Oct 2003, 403 


\section{Northern Ireland Legal Quarterly [Vol. 57, No. 3]}

Barnes v Addy. ${ }^{127}$ This is perhaps the reason for the Privy Council's attempt to clarify the position, and establish that the test is in fact an objective one, rather than the subjective test suggested by the words of the majority.

Nevertheless, with the devaluing of this equitable claim, it has been suggested that the common law may now be sufficiently equipped to deal with claims of this sort, through the mechanism of tort, specifically "a tort of interference with a fiduciary relationship". ${ }^{128}$ Such a tort would obviate the need for the convoluted interpretations of the concepts of honesty and dishonesty, and focus on the acts of the parties and their consequences. A review of the words of Lord Nicholls reveals that this is what may have been intended by him, but was subsequently derailed. This approach has already been attempted in Australia in the Queensland Supreme Court case of Voss v Davidson, ${ }^{129}$ in which alternative claims of tort and accessory liability were made against a solicitor. These claims failed on their facts. Nevertheless, it is indicative that this course is not one entirely without merit.

It may therefore be seen that the law of accessory liability has undergone substantial evolution in the 130 years since it was originally formulated as the second limb of Barnes $\mathrm{v}$ Addy. Originally it was necessary to establish fraud or dishonesty by a trustee, in which a third party knowingly assisted. Subsequently, it is no longer necessary - in Australia at least - to show dishonesty by the trustee, as the remedy focuses on the conduct of the third party, and not on that of the trustee. It is also now possible to impose liability for interference with any fiduciary relationship, not merely a trustee's duty. Finally, the issue of knowledge has been usurped by the powerful restatement of the law by Lord Nicholls in Royal Brunei Airlines $\mathrm{v}$ Tan and replaced with an objective test of dishonesty. In seeking to interpret and apply this test, the House of Lords has misconstrued the words of Lord Nicholls and inadvertently reverted to a knowledge-based liability, by imposing a subjective test of honesty on the third party. The effect of this position has been to weaken the position of the beneficiary, and render the remedy relatively difficult to obtain. Such is the legacy provided by Twinsectra v Yardley. 